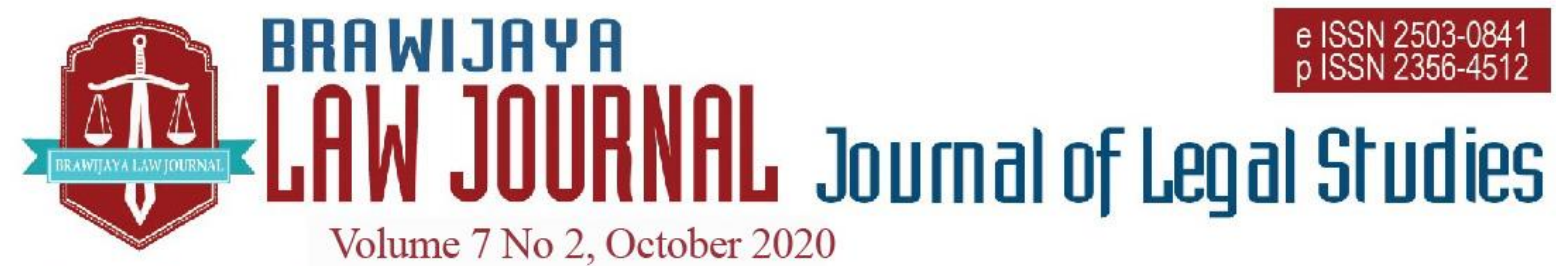

Nationally Accredited No. 30/E/KPT/2018 Dated 24th October 2018

This work is licensed under a Creative Commons Attribution-NonCommercial 4.0 International License

\title{
Legal Protection for Women Drivers in the Gig Economy: Evidence from Tulungagung, East Java
}

\author{
Ahmad Zulfiyan \\ Universitas Gadjah Mada, Indonesia \\ Email: ahmad.zulfiyan@mail.ugm.ac.id
}

Submitted : 2020-08-30 | Accepted : 2020-10-01

\begin{abstract}
In a patriarchal society, women tend to be vulnerable because of the existence of a hierarchical view that considers women in lower positions than men, including at work. This study aims to find out how the legal protection for Grab women drivers in the gig economy. The method used in this study is empirical-qualitative with a feminist approach. Data were collected through in-depth interviews, literature studies, and the internet. This study's data were analyzed using the Miles and Huberman model, which includes data reduction, display, and conclusion drawing. This study showed that, in the gig economy, the relationship between Grab as an online transportation service provider and the drivers that they call 'Mitra' cannot be categorized as an employment relationship. The implication is that drivers cannot obtain the rights stated in Act Number 13 of 2003 concerning Labor. Women drivers face various legal protection constraints, such as limited job security, double burden, gender stereotypes, and sexual harassment.
\end{abstract}

Keywords: legal protection; women drivers; gig economy; tulungagung.

\section{INTRODUCTION}

In a patriarchal society where women are considered inferior to men, women, and gender discourses are often discussed. This discourse mostly talks about gender inequality issues in the relationship between women and men. Patriarchy is the main nomenclature of feminism as a philosophy. ${ }^{1}$ Patriarchy views women are not equal to men.

Candraningrum, Dewi, 'Karier Patriarki' (2014) Jurnal Perempuan,

<https://www.jurnalperempuan.org/blog/dewicandraningrum-karier-patriarki $>$ (accessed 18 June 2020)
This inequality of relations has led to various gender injustices such as marginalization, subordination, gender stereotype, violence, and the double burden. ${ }^{2}$

Based on these injustices, feminists have tried to fight for women's rights as part of society. Several feminist groups consider patriarchy as the main enemy of the struggle for women's rights. However, patriarchy is

2 Mansour Fakih, Analisis Gender dan Transformasi Sosial, (Yogyakarta: Pustaka Pelajar, 2006) 
essentially fluid because it is a construction. This means that patriarchy can change. ${ }^{3}$ Thus, feminist sees this as an opportunity to fight for women's rights, including women's participation in development. Thus, feminist sees this as an opportunity to fight for women's rights, including women's participation in development. Feminism views women's participation in development as necessary. An increase in the number of women workers can increase their role in society and indicate that their participation is needed in the labor market. ${ }^{4}$

In traditional societies, working women are common, especially in the rural agricultural sector. ${ }^{5}$ There are many reasons why women decide to work, such as to help support their family economy or want to have self financial autonomy. ${ }^{6}$ Women's access to the labor market has increased but limited to the informal sector. This condition is caused by a capitalist system that views women as a 'dairy cow' and the dichotomy of gender roles that position women only in the domestic sphere. ${ }^{7}$ One example of women working in the informal sector can be seen from their participation as online ride-hailing drivers. Online ride-hailing is a product of technological developments in the gig economy.

3 Bennett, Judith M., History Matters: Patriarchy and the Challenge of Feminism, (Philadelphia: University of Pennsylvania Press, 2006)

4 Husni, Lalu \& Ani Suryani, 'Legal Protection for Women Domestic Workers Based on The International Convention' (2018) 21(2) Journal of Legal, Ethical, and Legulatory, 1.

5 Tjaja, Ratna P., 'Wanita Bekerja dan Implikasi Sosial,' (2000) 20 Jurnal Naskah, 3

6 M.Th. Handayani and Ni Wayan Putu Artini, 'Kontribusi Pendapatan Ibu Rumah Tangga Pembuat Makanan Olahan terhadap Pendapatan Keluarga,' (2009) 5(1) Jurnal PIRAMIDA.

7 Candraningrum, Dewi, 'Karier Patriarki,' (2014) Jurnal Perempuan,

$<$ https://www.jurnalperempuan.org/blog/dewicandraningrum-karier-patriarki $>$ (accessed 18 June 2020)
In the labor discourse, the gig economy is something new. This era is marked by the use of technology in carrying out business practices. The gig economy is an economic system that uses digital platforms to connect workers with clients. ${ }^{8}$ The platform serves to connect workers as 'sellers' and consumers as 'buyers' to interact. ${ }^{9}$ Several companies included in the gig economy in Indonesia are the duopoly of giant ride-hailing services, Grab and Go-Jek. This study focused on discussing Grab as one of the prominent online ride-hailing services in Indonesia.

However, the gig economy has brought new problems to labor, especially regarding the working relationship between companies and workers. Academics such as Bornstein (2015) ${ }^{10}$ and Healy, et. al. (2017) ${ }^{11}$ are worried that the rise of the gig economy will create new imbalances in the relationship between companies and workers. They said that this system gave companies the possibility to escape from various responsibilities for the rights workers should receive through various forms of disguise in the labor system. Apart from these systemic problems, the gig economy also impacts the increasingly unequal position of men and women in their work. In Grab's context, this has to do with masculinity in the world of

8 Brett Harris, 'Uber, lyft, and regulating the sharing economy,' (2017) 41(1)Seattle University Law Review, 275

9 Gerard Valenduc and Patricia Vendramin, 'Work in the digital economy: sorting the old from the new' (2016) Working Paper, 34

10 Bornstein, Josh, 'The Great Uber Fairness Fallacy: As a Driver, How Do You Bargain with an App?' The Guardian, 2015 $<$ https://www.theguardian.com/technology/2015/ aug/24/uber-fairness-independent-contractorsemployees-rights $>$ (accessed 1 June 2020)

11 Healy, Joshua and Et. Al., 'Should we take the gig economy seriously?' (2017) Labour \& Industry: a journal of the social and economic relations of work, DOI: 10.1080/10301763.2017.1377048, 10 
labor, which sees women only suitable for working in the domestic sphere rather than as ride-hailing drivers. In his report, Wargadiredja (2017) ${ }^{12}$ found that there is still a lot of discrimination against women online ride-hailing drivers who are proven to receive more order cancellations by consumers due to sexism in society.

Thus, it is important to have legal protection for women online ride-hailing workers in Indonesia, considering that they have a higher vulnerability level than most drivers. Indonesia has ratified The Convention of The Elimination of all Forms of Discrimination Against Women (CEDAW) through Law Number 7 of 1984 (concerning Ratification of the Convention on the Elimination of All Forms Discrimination Against Women). It has a consequence for the government to provide legal protection for women workers from various forms of discrimination, including women drivers working in the gig economy.

Based on this background, this study examined to find out how legal protection for Grab women drivers. This study took place in Tulungagung, Jawa Timur, where Grab is a monopoly online ride-hailing service since its appearance in mid-2017, considering that its biggest competitor, Go-Jek, has not yet penetrated the area.

\section{LEGAL MATERIALS AND METHODS}

For approximately five months from January to May 2020, the author conducted research concerning legal protection for Grab women drivers in Tulungagung, East Java.

12 Wargadiredja, Arzia T., 'Penyebab Pengendara Ojek Perempuan Rutin Ditolak Penumpang', VICE, 2017 <https://www.vice.com/id_id/article/xwawww/pe nyebab-pengendara-ojek-online-perempuan-rutinditolak-penumpang > (accessed 2 August 2020)
This study used a qualitative descriptive method with a feminist and empirical approach. Qualitative research can be used to understand social phenomena using the interaction process between the researcher and the phenomenon under study. ${ }^{13}$ The feminist approach positions gender as a lens that focuses on seeing women's experiences as the center of knowledge building. ${ }^{14}$ The field research was conducted in in-depth interviews and observation to six Grab women drivers in Tulungagung and secondary methods, including literature and internet studies.

Regarding legal material, this study used Act Number 13 of 2003 concerning Labor to analyze aspects of legal protection for Grab women drivers. The authors also confirmed research-based findings to a formal figure coming from academics, Nabiyla Risfa Izzati (researcher and lecturer of Faculty of Law at Universitas Gadjah Mada), who has been researching labor law for several times. The data analysis used refers to the Miles and Huberman model, which consists of three main data analysis processes, including data reduction, display, and conclusions drawing and verification.

\section{RESULT AND DISCUSSION}

\section{Gig Economy Effect: Unrecognized} Relationship between Grab and Drivers

In the gig economy, Grab has disrupted the concept of conventional transportation service that has been known for a long time. The word 'gig' is interpreted in various ways. 'Gig' first appeared in 1790, which means "small boat that bounces over and over". In

13 Haris Herdiansyah, Metodologi Penelitian Kualitatif untuk Ilmu-Ilmu Sosial, (Jakarta: Salemba Humanika, 2010) 10-12

14 Sri W. Eddyono, Women's Empowerment in Indonesia, A Poor Community in Jakarta, (New York: Routledge, 2019) 9 
1908, the word 'gig' was interpreted as a job that had three characteristics; always moving, fast, and not permanent. ${ }^{15}$ The gig economy is a symbol of changing the concept of work in the digital technology era because it has the flexibility of work and short-term work contracts. $^{16}$

In Indonesia, Grab is an online transportation service provider that plays in the duopoly market with Go-Jek. The two companies have the largest market in Indonesia, which has successfully expanded in hundreds of cities and made them a giant ride-hailing service provider in Indonesia. Grab first launched its service in 2012 in Malaysia under the name GrabTaxi. One year later, Grab expanded to the Philippines, Thailand, and Singapore. In 2014, Grab launched its GrabBike (motorbike-based rideshare) and GrabCar (car-based rideshare) services and began expanding to Indonesia and Vietnam. In 2018, Grab acquired Uber in the Southeast Asian market, which also eliminated Uber in the Indonesian market. ${ }^{17}$

Grab also marked the rise of the gig economy in Indonesia. Grab uses the rhetoric of freedom of work to convince their drivers to join and work hard. Through Grab official website, Grab offers 3 flexibility to their drivers; freedom to manage income, pursue dreams, and socialize. However, Yappy (2020) ${ }^{18}$ criticizes this assumption. In general, Yappy argued that the gig workers still have to set aside a portion of their income for third parties, making them less free to manage their income.

15 Shierly N. Yappy, 'Pekerja Gig dan Ekonomi Gig', Jawapos, 2020 https://www.jawapos.com/opini/12/01/2020/peker ja-gig-dan-ekonomi-gig/> (accessed 19 July 2020)

16 Woodcock, Jamie and Mark Graham, The Gig Economy; A Critical Introduction, (Polity Press: Cambridge, 2020)

17 Bharat, Shah S, 'The Driver-Partner Dilemma: Structural Transformation in Indonesia's On Demand Transportation Sector and Skills Traps
The relationship between Grab and their driver is different from their relationship with their employees at the head office. Grab chooses to use the term 'partner' to describe their driver. Grab's relationship with the drivers is mediated by an application that allows drivers to make money through a series of order mechanisms from customers or clients. This means that the company's relationship with the driver-partner is indirect, which allows the drivers to work flexibly.

Based on Act Number 13 of 2003 concerning Labor, a working relationship is defined as a relationship between a business owner and a worker based on a work agreement. The law explains that work relations have three conditions that must be fulfilled; work, wages, and orders. According to Nabiyla Risfa Izzati, an academic at the Faculty of Law-Universitas Gadjah Mada, Grab and the driver's relationship cannot be categorized as a working relationship because it does not meet these three requirements. ${ }^{19}$

Regarding wages and orders, Grab drivers do not get wages and orders from the company. Wages and orders are given by consumers directly through the application. The relationship between Grab and the driver is limited to an informal work relationship. The International Labor Organization (ILO) defined informal employment as both inside and outside informal employment, including independent work in unregistered companies and unprotected work. ${ }^{20}$ This informalization of employment relations, although it looks

among Go-Jek and Grab Driver Partners' (2017), Unpublished, p. 4-5.

18 Shierly N. Yappy, above n.15.

19 Interview with Nabiyla Risfa Izzati, 26 February 2020

20 Martha A. Chen, 'Rethinking the informal economy: linkages with the formal economy and the formal regulatory environment,' DESA Working Paper No. 46, (New York: UN 
like an expansion of employment opportunities, is the result of the inability of industry to create formal jobs. ${ }^{21}$

Although it looks tantalizing, this type of relationship is deceptive. Drivers are treated as informal workers who receive limited job protection. As a company, Grab can force drivers to continue to work hard. On the other hand, Grab eliminates drivers' rights as workers and imposes costs and risks on them. ${ }^{22} \mathrm{Grab}$, as an online transportation service provider, controls the allocation of jobs through the various regulations they make. However, the company is not directly responsible for what happens in the market created by the application platform they have initiated. As a result, drivers are vulnerable to work without adequate protection.

Nabiyla Risfa Izzati argued that there are several implications when Grab cannot be categorized as a transportation company. ${ }^{23}$ First, the rights and obligations stated in Act Number 13 of 2003 concerning Labor cannot be obtained by Grab drivers. Second, it is difficult for the government to intervene if there are problems regarding work. Consequently, there are many unfair policies, such as those stated in Grab's 'Terms of Service' or 'Term of Service' as follows: "Grab's failure to exercise any rights or provisions in terms of use will not be considered a waiver of these rights or conditions." 24

Although the company frees women Grab drivers to work flexibly, Grab would determine certain criteria that they must meet

Department of Economic and Social Affairs, 2007) 2-3

21 Marylin Carr and Martha Alter Chen, Globalization and the informal economy: how global trade and investment impact on the working poor (Geneva: International Labour Office, 2002) 5-6

22 Aulia Nastiti, 'Cerita pengemudi menguak eksploitasi Gojek, Grab, dan Uber', The to get work benefits. Drivers who successfully make at least 130 trips in 30 days will benefit from a priority offer (See Table 1).

Table 3.

Additional Criteria and Benefits for Grab Drivers

\begin{tabular}{|c|c|c|}
\hline Category & Criteria & Benefits \\
\hline Member & $\begin{array}{l}\text { Have an active } \\
\text { Grab driver } \\
\text { application }\end{array}$ & $\begin{array}{l}\text { GrabBenefits } \\
\text { offering }\end{array}$ \\
\hline Elite & $\begin{array}{l}\text { - Minimum of } 60 \\
\text { trips in the last } \\
30 \text { days } \\
\text { - An acceptance } \\
\text { value of at least } \\
70 \text { percent in the } \\
\text { last } 30 \text { days } \\
\text { - Minimum } 4.6 \\
\text { star rating in the } \\
\text { last } 30 \text { days } \\
\text { - Become a } \\
\text { member for at } \\
\text { least } 30 \text { days }\end{array}$ & $\begin{array}{l}\text { Priority offering } \\
\text { of GrabBenefits }\end{array}$ \\
\hline Elite+ & 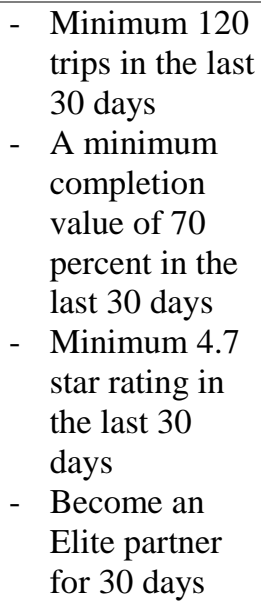 & $\begin{array}{l}\text { - GrabBenefits } \\
\text { priority } \\
\text { offering } \\
\text { - Priority service } \\
\text { at Grab Driver } \\
\text { Center (GDC) } \\
\text { - Any other } \\
\text { benefits }\end{array}$ \\
\hline
\end{tabular}

(Source: Grab driver application, processed by author)

Grab women drivers who fail to reach the specified target will not receive work benefits. Even when they have upgraded their level, Grab women drivers who are unable to

Conversation, 2017

$<$ https://theconversation.com/amp/ceritapengemudi-menguak-eksploitasi-di-gojek-grabdan-uber-84599> (accessed 15 August 2020).

23 Interview with Nabiyla Risfa Izzati, 26 February 2020

24 Grab Term of Service, point 27.1 
maintain their performance will experience a downgrade next month. Moreover, If the drivers' rating is below 5.0, they will be monitored, or worse, will not get any incentives. ${ }^{25}$ The implication is that women drivers of Grab who want to get benefits need to work harder. This finding is strengthened by the explanation of the official Twitter account@GrabID in a direct message as follows: "If performance is not achieved and there is a decline, it is possible that the elite level will be lifted or down."26

The relationship that underlies Grab and its drivers is a contractual partnership relation. Indonesia recognizes the Civil Code that regulates in general terms of contractual partnership agreements, to be precise in Article 1338 in conjunction with Article 1320. In particular, Articles 1618 to 1641 regulate the partnership relations as a legal relationship between partners by including certain capitals, as stated in articles 1618 and 1619 below:

"A civil company is an agreement between two or more people, who promise to include something in the company with the intention that the profits derived from the company are shared between them."27

"All civil companies must be shown something lawful and held for the common benefit of their members. Each member is obliged to put money, goods or business into the company." 28 The relationship between Grab and the drivers is full of power relations that place drivers in a vulnerable position. Grab drivers are in exploitative relationships without any guarantee of safety. ${ }^{29}$ On the other hand,

25 Interview with AW, 29 January 2020

26 Direct Message (DM) Twitter @ GrabID, 31 March 2020

27 Civil Code, article 1618

28 Civil Code, article 1618
Grab drivers are forced to do their best work. Grab drivers must provide the best service to passengers. If not, they will get sanctions ranging from mild to severe, even termination of the partnership. ${ }^{30}$

Although it looks tempting because of the flexibility of work, the partnership between Grab and the driver is actually just a mandatory fun. Mollick \& Rothbard (2014) call this kind of phenomenon gamification of work. Their work is fully 'forced' by employers in the work environment to achieve the employer's goals. The implication is, although drivers are required to compete to show their best performance to get work bonuses, they do not get guaranteed job security and their rights as workers as regulated by Act Number 13 of 2003 concerning Labor. If they cannot show their best performance according to company standards, they will not get work benefits and even get sanctions. Gamification of work in the world of work is a way for companies to escape their responsibilities as employers. I argue that increasing women's participation in work depends on how much access is given to them, both access to contributions and protection. If all that is fulfilled is access only, then protection will not be maximized, and work constraints will arise.

\section{Legal Protection Constrains Obtained by Grab Women Drivers}

Grab drivers are at work vulnerability because their relationship with Grab cannot be categorized as an employment relationship. Apart from not getting a minimum wage, the right to social security, and the right to organize an association, Grab

29 Interview with Nabiyla Risfa Izzati, 26 February 2020

30 Code of Conduct ( $\mathrm{CoC})$ of Grab drivers mentioned on Grab official website 
drivers also do not receive protection related to work safety. In the context of women drivers, this vulnerability is increasing because women are still considered to be lower than men. ${ }^{31}$ Based on the research finding, there are four main constraints regarding limited legal protection obtained Grab women drivers in Tulungagung.

Firstly, Grab women drivers have low job security. From an employee perspective, the relationship between Grab and women drivers can be said to be exploitative. Apart from not being included in the category of work relations according to Act Number 13 of 2003 concerning Labor, there are almost no regulations that specifically regulate the rights and obligations of informal relations like this in Indonesia. However, the Ministry of Transportation through the Regulation of the Minister of Transportation of the Republic of Indonesia Number PM 12 of 2019 concerning Safety Protection of Motorcycle Users Used for Public Interest regulates the certainty of drivers to get social security, as follows: "Certainty of obtaining employment social security protection and health social security in accordance with the provisions of laws and regulations. ${ }^{132}$

Referring to this regulation, women Grab drivers should receive social and health insurance from the company. Based on insurance-related guidelines on the official Grab website, Grab women drivers get work accident insurance from Salvus, which is post-incident. In order to make an insurance claim, the driver's application must be active

31 Joupy G. Z. Mambu, 'Aspek Perlindungan Hukum Terhadap Pekerja Wanita (Menurut UndangUndang Nomor 13 Tahun 2003)' (2010) 2(2) de Jure: Jurnal Syariah dan Hukum, 150

32 Regulation of the Minister of Transportation of the Republic of Indonesia Number PM 12 of 2019 concerning Safety Protection of Motorcycle Users Used for Public Interest, chapter V, article 16, point $3 \mathrm{i}$

33 Interview with AY, 3 February 2020 (on the bit) at the time of the incident. This insurance is limited and does not accommodate work accidents when Grab women drivers work without turning on the application. Even though there are several Grab women drivers who continue to take passengers even without the application running. ${ }^{33}$

Apart from Salvus, Grab women drivers have social security in the form of BPJS Ketenagakerjaan, which is independently managed because Grab does not accommodate the collective registration of Grab drivers to be registered under the BPJS. 34 In fact, the Ministry of Transportation has asked online ride-hailing companies, including Grab, to provide health protection to their drivers through BPJS. ${ }^{35}$ This finding shows that Grab has not implemented the goverment's appeal regarding the provision of job security through the BPJS for the drivers.

The second constraint faced by women drivers is the double burden of work. It is caused by the dichotomy of gender roles where women are considered only responsible for domestic affairs. In the context of working women, this has a consequence that women have to work longer. The concept of work like this is perpetuated by society, culturally and structurally. ${ }^{36}$ Women tend to view childcare and family as the most important. This is different from men as husbands who are seen as the main breadwinner, so that they have less

34 Interview with AW, 29 January 2020

35 Ariefana, Pebriansyah and Achmad Fauzi, 'Aturan Baru, Kemenhub Minta Grab dan Go-Jek Kasih BPJS ke Driver,' Suara.com, 2019, <https://www.suara.com/bisnis/2019/03/25/15063 6/aturan-baru-kemenhub-minta-grab-dan-go-jekkasih-bpjs-ke-driver> (accessed 15 August 2020).

36 Mansour Fakih, Analisis Gender dan Transformasi Sosial, (Yogyakarta: Pustaka Pelajar, 2006) 
dedication to domestic work. ${ }^{37}$ Even though their job as a Grab driver is flexible, women drivers still experience trade-offs between work and family. Their husband sometimes prohibits them from working at certain times because they are considered unsafe. This makes it difficult for them to work fully. ${ }^{38}$

Besides taking care of children, women Grab drivers are also faced with more complex matters, such as when a family member is sick. Grab women drivers are willing not to work for a long time until family members recover. They have to go back and forth from the hospital to take care of a family member who is sick. The drivers will back to work after finishing all domestic affairs. $^{39}$

Double burden is one of the crucial issues in working women's discourse double burden experienced by women as another form of gender discrimination. When men are considered to have only responsibility for public work (paid work), women bear two burdens at once: paid work and unpaid care work (UCW) in the domestic sphere. There is a relationship between the double burden experienced by women workers and capitalism. UCW actually has a big share in world development until now. ${ }^{40}$ Unfortunately, the double burden is often underestimated and benefits capitalism and harms working women. Even though women's participation in the labor market has increased, it does not necessarily increase men's participation in domestic work.

The important thing that needs to be underlined in this issue is the relationship between double burden and legal protection for women workers. At first glance, the double burden is one form of legal protection

37 Hunt, Abigail, and Et Al., Women in the gig economy Paid work, care and flexibility in Kenya and South Africa, (2019) ODI Report, p. 14-15.

38 Interview with EM, 4 February 2020 constraints against women. However, the author argues that the double burden is the root of the problem of legal protection for women workers. The problem has an impact on the making of labor policies related to women workers. On Grab women drivers, the paid work they do is disrupted by the double burden. Apart from working in the public sector, Grab drivers are still busy with UCW in the domestic sphere.

From a legal perspective, women's double burden has not been accommodated in the existing legal regulations in Indonesia. The government has not ratified ILO Convention Number 189 of 2011 concerning Decent Work for Domestic Workers. As a result, legal protection for women who work in the domestic sector is not fulfilled. Besides, Law Number 1 of 1974 concerning Marriage is inconsistent in regulating these problems. In article 31 point (1), this regulation states that husband and wife have an equal position and have the same rights in household life and social life. However, From a legal perspective, women's double burden has not been accommodated in Indonesia's existing legal regulations. Article 34 point (2) states that the wife has the obligation to manage household affairs properly. This inconsistency indicates that the government has not fully paid attention to women workers' double burden.

Three strategies that can be implemented to create equality in UCW: recognize, reduce, and redistribute. Recognition strategy is used to see how much opportunity women lose because of doing UCW. Furthermore, the reduce strategy is carried out to reduce women's lost opportunities due to doing UCW. Finally, the

\footnotetext{
39 Interview with AW, 29 January 2020

40 Silvia Federici, Revolution at Point Zero: Housework, Reproduction, and Feminist Struggle, (California: PM Press, 2017)
} 
redistribute strategy aims to redistribute the role of work in UCW not only for women, but also for men. ${ }^{41}$ Mulia (2019) ${ }^{42}$ criticizes the analogy of the relationship between men and women as captains and crew. Mulia argued that it would be more suitable if the relationship between men and women was analogous to a pilot and co-pilot having an egalitarian family position.

The third constraint is gender stereotype. In general, all informants admitted to having received gender stereotypes from the community, especially their neighbors. The label affixed to the Grab women driver makes them seen as a person who is always under suspicion when rarely at home. Many questions doubted the role of women in the world of work outside the home. Several informant told me that they get stereotypical commentaries from others regarding their job as Grab drivers. Many people think that the job of a driver is a job for men, not women. ${ }^{43}$ Besides that, there was an informant who was suspected by her neighbors of having an affair with another men because she often came home at night after working all day. ${ }^{44}$

Society tends to blame women when sexual harassment occurs instead of placing them as victims. This condition relates to the fourth constraint experienced by Grab women drivers: sexual harassment. Sexual harassment is a form of violence that is most often experienced by women in society. Sexual harassment occurs because of unequal power relations and a legal system that is not yet conducive to upholding justice and equality. The forms of sexual harassment

41 Diane Elson, 'Recognize, Reduce, and Redistribute Unpaid Care Work: How to Close the Gender Gap,' (2017) 26(2) New Labor Forum, 5559.

42 Siti Musdah Mulia, Ensiklopedia Mulimah Reformis, Pokok-Pokok Pemikiran untuk experienced by Grab women drivers vary. The majority of the harassment was done by customers or men who saw Grab women drivers at work, such as catcall and any other verbal harassment. ${ }^{45}$ Unfortunately, legal protections for workers who experience harassment in the workplace are not accommodated. In fact, the ILO has made regulations related to this through ILO Convention No. 190 of 2019 concerning the Elimination of Violence and Harassment in the World of Work. However, Indonesia has not yet ratified the convention.

\section{Legal Dilemmas in the Relationship between Grab and Women Drivers}

Apart from work flexibility, Grab also entices its drivers to be their own boss without any orders from their employers. This gives the impression that the two parties have an equal position. Even so, Grab women drivers have diverse thoughts in this regard. The results of this study explain that Grab women drivers, on the one hand, think that work flexibility can make it easier for them to do other things outside of their work, such as taking care of their family, spending time with children, and enjoying free time. ${ }^{46}$

On the other hand, there are women Grab drivers who wish for a permanent job with consideration of guaranteed income and job security. Work flexibility, although it makes it easier to do other activities, is considered not to have good prospects in terms of income and job security. Grab women drivers to assess this type of work as having a high risk and allows them to earn an uncertain income. ${ }^{47}$

Reinterpretasi dan Aksi, (Jakarta: Dian Rakyat, 2019) 68

43 Interview with TS, 5 February 2020

44 Interview with DW, 29 January 2020

45 Interview with AW, 29 January 2020

46 Interview with AW, 29 January 2020

47 Interview with EM, 4 February 2020 
Although having the same background, housewives who have children, the diversity of thoughts of women Grab drivers regarding whether they prefer to be flexible workers or permanent workers is interesting. Each of these desires has a consequence in which drivers who agree with flexible work pay more attention to the factor of comfort and time flexibility. Meanwhile, drivers who agree with permanent work see safety and job security as essential factors.

\section{CONCLUSION}

The company's relationship with Grab women drivers cannot be categorized as an employment relationship under Act Number 13 of 2003 concerning Labor. The implication is that the rights and obligations stated in the regulation cannot be imposed on companies or women drivers. It is difficult for the government to intervene because there is no regulation that regulates it. The informal relationship with the rhetoric of flexible and equal employment that occurs between companies and Grab women drivers has resulted in various legal protection constraints such as a lack of job security, double burden, gender stereotypes from society, and violence in the form of sexual harassment.

The government needs to provide legal regulation that specifically regulates legal protection for online ride-hailing drivers, particularly for women drivers. Also, the government needs to ratify ILO Convention No. 190 of 2019 concerning the Elimination of Violence and Harassment in the World of Work to protect workers from various forms of violence and harassment and ILO Convention Number 189 of 2011 concerning Decent Work for Domestic Workers to protect women who work in the domestic sector.

\section{ACKNOWLEDGEMENT}

I gratefully thank Sri Wiyanti Eddyono, S.H. LL.M. (HR) Ph.D. (lecturer and the Director of the Law, Gender and Society Research Centre, Faculty of Law, Universitas Gadjah Mada) and Prof. Dr. Sri Rum Giyarsih, M.Si. (lecturer of Faculty of Geography, Universitas Gadjah Mada) for the comments on the manuscript.

\section{REFERENCES}

\section{Book}

Bennett, Judith M., History Matters: Patriarchy and the Challenge of Feminism, (Philadelphia: University of Pennsylvania Press, 2006).

Carr, Marylin and Martha Alter Chen, Globalization and the informal economy: how global trade and investment impact on the working poor (Geneva: International Labour Office, 2002).

Eddyono, Sri W., Women's Empowerment in Indonesia, A Poor Community in Jakarta, (New York: Routledge, 2019). Fakih, Mansour, Analisis Gender dan Transformasi Sosial, (Yogyakarta: Pustaka Pelajar, 2006)

Federici, Silvia, Revolution at Point Zero: Housework, Reproduction, and Feminist Struggle, (California: PM Press, 2012).

Hawkesworth, Mary, Truth and truth in feminist knowledge production, in The handbook offeminist research: Theory and praxis (2nd ed.), edited by Sharlene N. Hesse-Biber, (California: SAGE Publication, 2012).

Herdiansyah, Haris, Metodologi Penelitian Kualitatif untuk Ilmu-Ilmu Sosial, (Jakarta:Salemba Humanika, 2010).

Mulia, Siti M., Ensiklopedia Mulimah Reformis, Pokok-Pokok Pemikiran 
untuk Reinterpretasi dan Aksi, (Jakarta: Dian Rakyat, 2019).

\section{Article}

Bharat, Shah S, 'The Driver-Partner Dilemma: Structural Transformation in Indonesia's On Demand Transportation Sector and Skills-Traps among Go-Jek and Grab DriverPartners,' (2017) Unpublished.

Bornstein, Josh, 'The Great Uber Fairness Fallacy: As a Driver, How Do You Bargain with an App?' The Guardian, 2015

$<$ https://www.theguardian.com/techno logy/2015/aug/24/uber-fairnessindependent-contractors-employeesrights $>$ (accessed 1 June 2020).

Candraningrum, Dewi, 'Karier Patriarki' (2014) Jurnal Perempuan, $<$ https://www.jurnalperempuan.org/bl og/dewi-candraningrum-karierpatriarki> (accessed 18 June 2020).

Chen, Martha A., 'Rethinking the informal economy: linkages with the formal economy and the formal regulatory environment,' DESA Working Paper No. 46, (New York: UN Department of Economic and Social Affairs, 2007).

Elson, Diane, 'Recognize, Reduce, and Redistribute Unpaid Care Work: How to Close the Gender Gap' (2017) 26(2) New Labor Forum, 52-61.

Handayani, M.Th. and Ni Wayan Putu Artini, 'Kontribusi Pendapatan Ibu Rumah Tangga Pembuat Makanan Olahan terhadap Pendapatan Keluarga' (2009) 5(1) Jurnal PIRAMIDA.

Harris, Brett, 'Uber, lyft, and regulating the sharing economy' (2017) 41(1) Seattle University Law Review, 269-285.

Healy, Joshua and Et. Al., 'Should we take the gig economy seriously?' (2017) Labour \& Industry: a journal of the social and economic relations of work, DOI:

10.1080/10301763.2017.1377048.

Hesse-Biber, Sharlene N., Feminist research: Exploring, interrogating, and transforming the interconnections of epistemology, methodology, and method, in The handbook of feminist research: Theory and praxis (2nd ed.), edited by Sharlene N. Hesse-Biber, (California: SAGE Publication, 2012).

Hunt, Abigail, and Et Al., 'Women in the gig economy Paid work, care and flexibility in Kenya and South Africa.' (2019) ODI Report, November.

Husni, Lalu \& Ani Suryani, 'Legal Protection for Women Domestic Workers Based on The International Convention' (2018) 21(2) Journal of Legal, Ethical, and Regulatory.

Izzati, Nabiyla R., 'The Changing Concept of Work in Gig Economy: Case of Go-Jek Driver and Its Social Protection' (2018) Proceeding of International Conference on Population and Social Policy in a Disrupted World, p. 50-69.

Mambu, Joupy G. Z., 'Aspek Perlindungan Hukum Terhadap Pekerja Wanita (Menurut Undang-Undang Nomor 13 Tahun 2003)' (2010) 2(2) de Jure: Jurnal Syariah dan Hukum, 150-161.

Mollick, Ethan R. and Nancy Rothbard, 'Mandatory Fun: Consent, Gamification and the Impact of Games at Work' (2014) The Wharton School Research Paper Series.

Nastiti, Aulia, 'Cerita pengemudi menguak eksploitasi Gojek, Grab, dan Uber', The Conversation, 2017 $<$ https://theconversation.com/amp/ceri ta-pengemudi-menguak-eksploitasi-digojek-grab-dan-uber-84599> (accessed 15 August 2020). 
Shibata, Saori, 'Gig Work and the Discourse of Autonomy: Fictitious Freedom in Japan's Digital Economy' (2019) New Political Economy.

Ariefana, Pebriansyah and Achmad Fauzi, 'Aturan Baru, Kemenhub Minta Grab dan Go-Jek Kasih BPJS ke Driver' Suara.com, 2019, $<$ https://www.suara.com/bisnis/2019/0 3/25/150636/aturan-baru-kemenhubminta-grab-dan-go-jek-kasih-bpjs-kedriver> (accessed 15 August 2020).

Tjaja, Ratna P., 'Wanita Bekerja dan Implikasi Sosial,' (2000) 20 Jurnal Naskah.

Valenduc, Gerard and Patricia Vendramin, 'Work in the digital economy: sorting the old from the new' (2016) Working Paper.

Wargadiredja, Arzia T., 'Penyebab Pengendara Ojek Perempuan Rutin Ditolak Penumpang', VICE, 2017 $<$ https://www.vice.com/id_id/article/x wawww/penyebab-pengendara-ojekonline-perempuan-rutin-ditolakpenumpang> (accessed 2 August 2020). Woodcock, Jamie and Mark Graham, The Gig Economy; A Critical Introduction, (Polity Press: Cambridge, 2020).
Yappy, Shierly N., Pekerja Gig dan Ekonomi Gig, Jawapos, 2020 <https://www.jawapos.com/opini/12/0 1/2020/pekerja-gig-dan-ekonomigig/> (accessed 19 July 2020).

\section{Legislations}

Civil Code

Regulation of the Minister of Transportation of the Republic of Indonesia Number PM 12 of 2019 concerning Safety Protection of Motorcycle Users Used for Public Interest

Law Number 1 of 1974 concerning Marriage Law Number 7 of 1984 concerning Ratification of the Convention on the Elimination of All Forms of Discrimination Against Women

Act Number 13 of 2003 concerning Labor

\section{Interviews}

Interview with AY, 4/2/2020

Interview with AW, 29/1/2020

Interview with DW, 29/1/2020

Interview with EM, 4/2/2020

Interview with HVF, 4/2/2020

Interview with Nabiyla Risfa Izzati, $26 / 2 / 2020$

Interview with NRM, 29/1/2020

Interview with TS, 5/2/2020 